\title{
ANALYSIS OF PERIPHERAL BLOOD LYMPHOCYTES IN BURNS OF VARYING DEGREES IN THE ASSESSMENT OF IMMMUNE SUPPRESSION
}

\author{
Arslanagic Selma, ${ }^{1}$ Karamehic Jasenko ${ }^{2}$ \\ ${ }^{1}$ Clinic for Reconstructive and plastic surgery, \\ University Medical Center Sarajevo, Sarajevo, Bosnia and Herzegovina \\ ${ }^{2}$ Institute of Immunology, University Medical Center Sarajevo, \\ Sarajevo, Bosnia and Herzegovina
}

Primljen/Received 30. 08. 2020. god.

Abstract: Introduction: Burn, depending on the degree of severity and depth, induces significant pathophysiological response of the body. Our study is the prospective study for assessment of $\mathrm{T}$ lymphocyte immunological changes in patients with burns, with different degrees of \%TBSA and depth of burns.

Research objectives: Objectives of this study were to assess $\% \mathrm{CD} 3+\mathrm{Ly}, \% \mathrm{CD} 4+\mathrm{Ly}, \% \mathrm{CD} 8+\mathrm{Ly}, \% \mathrm{CD} 3+$ HLA-DR+Ly, \%CD4+Ly /CD8+Ly), of burned body with different \%TBSA degrees, different depth burns and to establish predictive value of of immune suppression these parameters.

Patients and methods: According to \%TBSA, patients were classified into three groups: mild burns with TBSA $\%<15 \%$ (30 patients), group of medium burns with \%TBSA from 15\%-25\% (30 patients) and group with $\%$ TBSA $>25 \%$ to $40 \%$ (30 patients). According to the depth of burns, patients were classified into two groups, partial-thickness burns, (39 patients), and full-thickness burns (51 patients). We followed laboratory parameters: \% CD3+Ly, \% CD3+CD4+Ly, \% CD3+CD8+Ly, \% CD3+HLA-DR+Ly, CD4 / CD8 (\%) lymphocytes (on day $7^{\text {th }}$ and on day $14^{\text {th }}$ ).

Results: Percentage of CD3+ lymphocytes was significantly lower in severe burns compared to the moderate heavy burns andsignificantly lower compared to the mild burns. Percentage of CD3+CD4+ lymphocytes was significantly lower in severe burns compared to moderate heavy burns and in relation to mild burns (results on day $14^{\text {th }}$ ); also are lower in moderate severe burn compared to mild burns. On day $14^{\text {th }}$, the $\%$ CD4 / CD8 ratio was not significantly lower in the severe burns versus the moderate burns. On day $14^{\text {th }}$, the
Prihvaćen/Accepted 02. 12. 2020. god.

\% CD4 / CD8 ratio wassignificantly lower in severe burns compared to mild burns; significantly lower in moderateburns compared to mild burns. \% CD3+HLA -DR + cells was significantly lower in severe burn and moderately severe burns compared to the mild burns on day $7^{\text {th }}$, and also on day $14^{\text {th }}$. Full- thickness burns have significantly lower \%CD3+lymphocytes, $\% \mathrm{CD} 3$ $+\mathrm{CD} 4+$ lymphocytes, \%CD3+HLA-DR+ lymphocytes, ratio of \% CD4/CD8 lymphocytes compared to partial-thickness burns.

Conclusions: Peripheral blood T lymphocytes are one of the key indicators of immunosuppression of patients with burns of different \% TBSA and different degrees of burn depth. Larger \%TBSA and full- thickness burns injected stronger systemic immunosuppresion, compared to smaller \%TBSA and partial-thickness burns.

Key words: burn, \%TBSA, T lymphocytes, thickness of burns, \% CD3+Ly, \% CD3+CD4+Ly, \% CD3+ CD8+Ly, \% CD3+HLA-DR+Ly, ratio \% CD4 / CD8 lymphocytes.

\section{INTRODUCTION}

Globally, burns are one of the most common thermal injuries (1). Loss of skin barrier function, tissue ischemia and tissue destruction after burns and plasmorrhea over burnt surfaces are just some of the causes that are cited as possible reasons leading to an acute phase response, hematological and immune response in a burnt person. The immune response of the organism after a burn is very complex and is caused by a number of factors. The immune response is initially pro-inflammatory, but later becomes predominantly 
anti-inflammatory in order to maintain the organism's homeostasis and restore normal physiological processes. Both responses are mediated by cytokines and the cellular response. The central role in the regulation of the cellular adaptive immune response belongs to lymphocytes, especially CD4 + lymphocytes (2).

\section{RESEARCH OBJECTIVES}

The aim of the study was to examine how different degrees of $\%$ TBSA and depth of burn affect the T lymphocyte immune response: \% CD3 + Ly,\% CD4 + Ly, \% CD8 + Ly, \% CD3 + HLA-DR + Ly and the ratio of $\% \mathrm{CD} 4+\mathrm{Ly} / \% \mathrm{CD} 8+$ lymphocytes, monitoring the dynamics of parameters on the day $7^{\text {th }}$ day and on day $14^{\text {th }}$ after the burn; then the correlation of the examined parameters with the different $\%$ TBSA and the depth of the burn, and determine the predictive significance of individual laboratory parameters for the assessment of immune deficiency.

\section{PATIENTS AND METHODS}

The study is a prospective clinical study of patients with burns conducted at the Clinic for Reconstructive and Plastic Surgery of the University Medical Center in Sarajevo (UCC).

The survey was conducted from 2010 to 2017. The study was approved by the UCC Bioethics Committee No. 1893/2009. The study included 90 patients with varying degrees of severity of thermal trauma, aged 18 to 65 years, both sexes, with $\%$ TBSA to $40 \%$. The study excluded: patients younger than 18 years and older than 65 years; patients who could not be followed from the beginning of the burn, because they were already treated in another center, and then transferred to the UCC in Sarajevo, due to complications; patients diagnosed with fresh myocardial infarction; patients with already diagnosed cancer of any organ; patients with $>40 \%$ TBSA because we could not monitor the dynamics of target laboratory immune parameters in the planned days; patients diagnosed with liver failure, malnutrition, and hypoproteinemia prior to burn; patients with already diagnosed autoimmune diseases, patients undergoing immunosuppressive therapy and patients with burns caused by electric, chemical and radiation burns.

The examination was performed on the basis of the usual approach to the patient with burns by the method of anamnesis and objective medical examination with special reference to the local status of the burn skin. Patients with burns were classified according to the generally accepted classification of burns by the American Burns Association (3). According to the severity of the burn, patients were classified into three groups: group of mild burns with $\%$ TBSA $<15 \%$ (30 patients), group of moderate burns, with $\%$ TBSA of $15 \%-25 \%$ (30 patients) and group of severe burns with $\%$ TBSA $>25 \%$ to $40 \%$ TBSA (30 patients). According to the depth of the burn, we divided the patients into two groups. In group I, partial-thickness burns (39 patients), and in group II, full-thickness burns, (51 patients). We did not have patients with grade IV in this study.

We examined the values of $\%$ CD3 + Ly, \% CD4 + Ly, \% CD8 + Ly, activated lymphocytes (\% CD3 + HLA-DR + Ly) and the ratio of CD4 + Ly / CD8 + lymphocytes on the day $7^{\text {th }}$ and day $14^{\text {th }}$ after burn in patients with severe burns, and compared values of the examined parameters with values in patients with moderate burns and with mild burns. The same immune parameters were examined and statistically analyzed in the group of partial-thickness burns, compared to full-thickness burns. We examined the predictor significance of laboratory parameters for assessment the degree of immune deficiency on the day $7^{\text {th }}$ and the day $14^{\text {th }}$ after the burn trauma. We examined the correlation of $\%$ TBSA with the already listed laboratory parameters on the day $7^{\text {th }}$ and on the day $14^{\text {th }}$ after burn trauma.

We determined $\%$ CD3 + Ly, \% CD3 + CD $4+$ Ly, $\% \mathrm{CD} 3+\mathrm{CD} 8+\mathrm{Ly}, \%$ CD3 + HLA-DR + Ly, \% CD 4 / CD8 lymphocytes by flow cytometry, at the Institute of Immunology, UCC Sarajevo. The device on which the test was performed is CytometerBeckton Dickenson FACS Canto II, year of production 2009. Reference values by this method for CD3 + lymphocytes are $59 \%-85 \%$, for CD8 + lymphocytes: $11-38 \%$, for CD4 + lymphocytes: $30-59 \%$, the ratio of CD4 / CD8 lymphocytes by this methodis $0.9-3.6 \%$, and for CD3 + HLADR + lymphocytes it is $0-10 \%$.

All procedures performed in studies involving human participants were in accordance with the ethical standards of the institutional and/or national research committee and with the 1964 Helsinki declaration.

\section{Statistical data}

All data collected by this study were prepared for statistical evaluation and stored in the Exel 2010 program, Microsoft Office software package (Microsoft USA), while statistical processing was done in the statistical data processing program SPSS ver.20.

In the part related to descriptive statistics, for all data, depending on the distribution (normal or asymmetric), the following values are shown: absolute frequency $(\mathrm{N})$, structure index $(\%)$, average value $(\mathrm{X})$, standard deviation (SD), median (M) and interquartilerank (IQR). Student t-testwas done for dependent and independent samples of normal data distribution in order to assess the difference between the two groups. 
The Mann Whitney U test was done to compare results between two groups, an asymmetric data distribution. The ANOVA test, for symmetrical distribution of data, was applied to compare the obtained results of several examined groups (mild, moderate and severe burns) by days. The Kruskal Wallis test, for asymmetric data distribution, was applied to compare the obtained results of several examined groups (mild, moderate and severe burns) by days. A linear multivariate regression model was used to assess the predictor effect of individual variables (laboratory tests) on the dependent variable (\% TBSA). The chi square test (X2 test) was applied to analyze the relationships between frequencies. Values of $p<0.05$ were accepted as statistically significant. The results of all performed analyzes are presented in a table.

\section{RESULTS}

Out of a total of 90 burnt patients, 60 were male patients $(66.6 \%)$ and 30were female patients $(33.4 \%)$. Thirty patients had mild burns, 30 patients had moderate burns, and 30 patients had severe burns. 39 patients had partial-thickness burns and 51 patients had full-thickness burns.

Statistical analysis of the incidence of burns, according to the severity of the burn and the sex of the patients, we did not find a statistically significant difference, $p=0.638$. Statistical analysis of the average age of disease in men between mild, moderate and severe burns, we did not find a significant difference, $\mathrm{p}=$ 0.542. Statistical analysis of the average age of disease in women between mild, moderate and severe burns, we did not find a significant difference, $\mathrm{p}=0.628$. Mild burns had an average $\%$ TBSA of $7.9 \pm 2.4$, moderate burns had an average $\%$ TBSA of $19.5 \pm 2.7$, while severe burns had an average $\%$ of TBSA of $32.6 \pm 4.5$. There is a significant difference in $\%$ TBSA between mild, moderate and severe burns, $\mathrm{p}<0.0005$. We did not find a significant difference in the frequency of the number of patients with full-thickness burns in relation to partial-thickness burns, $\mathrm{p}=0.342$, Table 1 .

\section{Analysis of \%CD3 + lymphocytes in burns of varying degrees}

Mean values of CD3 + (\%) lymphocytes were significantly lower in the group with moderate burns and severe burns compared to mild burns on the day $7^{\text {th }}$ andon the day $14^{\text {th }}, \mathrm{p}<0.0005$. The average values of CD3 + (\%) lymphocytes were not significantly lower in severe burns compared to moderate severe burns on the day $7^{\text {th }}, p=0.769$ and on the day $14^{\text {th }}, p=0.329$.

Mean values of CD3 + (\%) lymphocytes were significantly lower by severe burns on the day $7^{\text {th }}$ and on the day $14^{\text {th }}$, compared to moderate severe burns and compared to mild burns; $\mathrm{p}<0.0005$. Mean values of CD3 + (\%) lymphocytes were significantly lower by moderate severe burns compared to mild burns; $\mathrm{p}<$ 0.0005 . In all groups of burns on day $14^{\text {th }}$, there was an

Table 1. Demographic and clinical characteristic of the patients according to the degree of severity and depth of the burn

\begin{tabular}{|l|c|c|c|c|}
\hline \multirow{2}{*}{} & \multicolumn{2}{|c|}{ THE SEVERITY OF THE BURN } & \multirow{2}{*}{ significance } \\
\cline { 2 - 5 } & mild burns & moderate burns & severe burns & \\
\hline Number & 30 & 30 & 30 & \\
\hline Men/women relationship & $22 / 8$ & $19 / 11$ & $19 / 11$ & $\mathrm{P}=0.638$ \\
\hline Average age of men \pm SD & $45.8 \pm 15.1$ & $43.8 \pm 15.0$ & $42.7 \pm 12.9$ & $\mathrm{P}=0.542$ \\
\hline Average age of women \pm SD & $48.7 \pm 10.6$ & $50.8 \pm 9.2$ & $45.3 \pm 3.2$ & $\mathrm{P}=0.628$ \\
\hline The average severity of the burn \pm SD & $7.9 \pm 2.4$ & $19.5 \pm 2.7$ & $32.6 \pm 4.5$ & $\mathrm{P}<0.0005$ \\
\hline $\begin{array}{l}\text { Partial thicknes burns/ Full thickness } \\
\text { burns }\end{array}$ & $15 / 15$ & $13 / 17$ & $11 / 19$ & $\mathrm{P}=0.342$ \\
\hline
\end{tabular}

Legend: SD- standard deviation

Table 2. Analysis of CD3+(\%) lymphocytes between the examined groups on the $7^{\text {th }}$ and $14^{\text {th }}$ after burn trauma

\begin{tabular}{|c|c|c|c|c|}
\hline \multirow{2}{*}{ DAYS } & \multicolumn{2}{|c|}{ DEGREE OF SEVERITY OF THE BURN } & \multirow{2}{*}{ significance } \\
\cline { 2 - 4 } & Mild burn & Moderate burns & Severe burns & \multirow{2}{*}{} \\
\cline { 2 - 4 } & $\mathrm{X} \pm \mathrm{SD}$ & $\mathrm{X} \pm \mathrm{SD}$ & $\mathrm{X} \pm \mathrm{SD}$ & \\
\hline $7^{\text {th }}$ day & $64.8 \pm 7.0$ & $54.0 \pm 7.4$ & $53.2 \pm 7.0$ & $\mathrm{P}<0,0005$ \\
\hline $14^{\text {th }}$ day & $68.6 \pm 7.1$ & $59.6 \pm 6.5$ & $56.5 \pm 9.2$ & $\mathrm{P}<005$ \\
\hline
\end{tabular}

Legend: $\mathrm{X}$ - average value, SD- standard deviation 
Table 3. Analysis of CD3+CD4+(\%) lymphocytes between the examined groups on the $7^{\text {th }}$ and $14^{\text {th }}$ day after burn trauma

\begin{tabular}{|c|c|c|c|c|}
\hline \multirow{2}{*}{ DAYS } & \multicolumn{2}{|c|}{ DEGREE OF SEVERITY OF THE BURN } & \multirow{2}{*}{ significance } \\
\cline { 2 - 4 } & Mild burn & Moderate burns & Severe burns & \multirow{2}{*}{$\mathrm{P}<0,0005$} \\
\cline { 2 - 4 } & $\mathrm{X} \pm \mathrm{SD}$ & $\mathrm{X} \pm \mathrm{SD}$ & $\mathrm{X} \pm \mathrm{SD}$ & \\
\hline $7^{\text {th }}$ day & $57.0 \pm 7.0$ & $52.8 \pm 8.6$ & $38.6 \pm 6.3$ & $\mathrm{P}<0,0005$ \\
\hline $14^{\text {th }}$ day & $55.3 \pm 7.1$ & $44.7 \pm 8.3$ & $33.1 \pm 7.9$ & \\
\hline
\end{tabular}

Legend: X- average value, SD- standard deviation

Table 4. Analysis of CD3+CD8+(\%) lymphocytes between the examined groups on the $7^{\text {th }}$ and $14^{\text {th }}$ day after burn trauma

\begin{tabular}{|c|c|c|c|c|}
\hline \multirow{2}{*}{ DAYS } & \multicolumn{2}{|c|}{ DEGREE OF SEVERITY OF THE BURN } & \multirow{2}{*}{ significance } \\
\cline { 2 - 4 } & Mild burn & Moderate burns & Severe burns & \multirow{2}{*}{$\mathrm{P}=0.150$} \\
\cline { 2 - 4 } & $\mathrm{M}(\mathrm{IQR})$ & $\mathrm{M}(\mathrm{IQR})$ & $\mathrm{M}(\mathrm{IQR})$ & \\
\hline $7^{\text {th }}$ day & $22.2(17.5-26.5)$ & $21.9(16.5-25.2)$ & $19.5(14.7-24.5)$ & $\mathrm{P}=0.060$ \\
\hline $14^{\text {th }}$ day & $25.3(18.1-28.5)$ & $22.6(16.4-27.2)$ & $20.4(16.9-22.6)$ & \\
\hline
\end{tabular}

Legend: M- median, IQR- interquarterly rank

Table 5. Analysis of $\% C D 4 / C D 8$ lymphocytes between the examined groups on the $7^{\text {th }}$ and $14^{\text {th }}$ day after burn trauma

\begin{tabular}{|c|c|c|c|c|}
\hline \multirow{2}{*}{ DAYS } & \multicolumn{2}{|c|}{ DEGREE OF SEVERITY OF THE BURN } & \multirow{2}{*}{ significance } \\
\cline { 2 - 4 } & Mild burn & Moderate burns & Severe burns & \multirow{2}{*}{$\mathrm{P}(\mathrm{IQR})$} \\
\cline { 2 - 4 } & $\mathrm{M}(\mathrm{IQR})$ & $\mathrm{M}(\mathrm{IQR})$ & $2.1(1.8-2.6)$ & $\mathrm{P}<0005$ \\
\hline $7^{\text {th }}$ day & $2.7(2.5-3.0)$ & $2.4(2.0-2.7)$ & $1.9(1.5-2.1)$ & $\mathrm{P}<0,0005$ \\
\hline $14^{\text {th }}$ day & $2.6(2.0-3.1)$ & $2.1(1.8-2.6)$ & 1.005 \\
\hline
\end{tabular}

Legend: M- median, IQR- interquarterly rank

increase in the average values of CD3 + (\%) lymphocytes compared to day $7^{\text {th }}$, but this increase was significant only in mild burns, $\mathrm{p}=0.041$ and in moderate burns, $\mathrm{p}=0.004$, Table 2 .

\section{Analysis of CD3 + CD4 + (\%) lymphocytes in burns of varying degrees}

On the day $7^{\text {th }}$ after burn trauma, the mean values of CD3+CD4+(\%) lymphocytes were significantly lower in severe burns compared to moderate burns and also compared to mild burns, $\mathrm{p}<0.0005$, but did not significantly differ between moderate burns compared to mild burns $\mathrm{p}=0.097$. On the day $14^{\text {th }}$ after burn trauma, the average values of CD3+CD4+(\%) lymphocytes were significantly lower in severe burns compared to moderate severeburns and compared to mild burns, $\mathrm{p}<$ 0.0005 . The average values of CD3+CD4+(\%) lymphocytes was significantly lower in moderate burns compared to mild burns, $\mathrm{p}<0.0005$, Table 3 .

\section{Analysis of CD3+ CD8 + (\%) lymphocytes in burns of varying degrees}

By statistical analysis of the mean values of CD3+ CD $8+(\%)$ lymphocytes between mild burns, moderate burns and severe burns, we proved that there is no significant difference between the groups of burns on the day $7^{\text {th }}, \mathrm{p}=0.150$, nor on day $14^{\text {th }}, \mathrm{p}=0.060$. On the day $14^{\text {th }}$, there was an increase in CD3+CD $8+(\%)$ lymphocytes compared to day $7^{\text {th }}$ in all three groups of burns. However, statistical analysis did not find a significant increase in CD3 + CD8 + (\%) lymphocytes either in the group of mild burns, $\mathrm{p}=0.090$, or in the group of moderate burns, $p=0.556$, as well as in the group of severe burns, $\mathrm{p}=0.742$, on the $14^{\text {th }}$ day compared to day $7^{\text {th }}$, Table 4.

\section{Analysis of ratio \% CD4 / CD8 lymphocytes in burns of varying degrees}

On the seventh day, the ratio of \% CD4 / CD8 is lower in severe burns compared to moderate burns, $\mathrm{p}=$ 0.040 ; and compared to mild burns, $\mathrm{p}=0.011$; it is lower in moderate severe burns compared to mild burns, $\mathrm{p}=0.041$. On the day $14^{\text {th }}$, the ratio\% CD4 / CD8 was not significantly lower in the severe burns compared to moderatesevere burns, $\mathrm{p}=0.106$; it is significantly lower in severe burns compared to mild burns, $\mathrm{p}=0.039$; it is significantly lower in moderate burns compared to mild burns, $\mathrm{p}=0.043$. 
Table 6. Analysis of CD3+HLADR+(\%) lymphocytes between the examined groups on the $7^{\text {th }}$ and $14^{\text {th }}$ day after burn trauma

\begin{tabular}{|c|c|c|c|c|}
\hline \multirow{2}{*}{ DAYS } & \multicolumn{3}{|c|}{ DEGREE OF SEVERITY OF THE BURN } & \multirow{2}{*}{ significance } \\
\cline { 2 - 4 } & Mild burn & Moderate burns & Severe burns & \\
\cline { 2 - 4 } & $\mathrm{X} \pm \mathrm{SD}$ & $\mathrm{X} \pm \mathrm{SD}$ & $\mathrm{X} \pm \mathrm{SD}$ & \\
\hline $7^{\text {th }}$ day & $10.1 \pm 1.4$ & $9.3 \pm 1.4$ & $9.0 \pm 1.6$ & $\mathrm{P}=0.021$ \\
\hline $14^{\text {th }}$ day & $11.9 \pm 1.7$ & $11.1 \pm 1.8$ & $10.2 \pm 1.7$ & $\mathrm{P}=0.003$ \\
\hline
\end{tabular}

Legend: X- average value, SD- standard deviation

Table 7. Analysis of laboratory parameters according to the degree of burn depth on the seventh day after burn trauma

\begin{tabular}{|l|c|c|c|}
\hline \multirow{2}{*}{ Laboratory parameters } & \multicolumn{2}{|c|}{ DEGREE OF BURN DEPTH } & \multirow{2}{*}{ significance } \\
\cline { 2 - 3 } & $\begin{array}{c}\text { Partial thickness burn } \\
\text { M(IQR) }\end{array}$ & $\begin{array}{c}\text { Full thickness burn } \\
\text { M(IQR) }\end{array}$ & \\
\hline$\% \mathrm{CD} 3$ & $62.3(58.1-68.8)$ & $53.8(48.3-53.8)$ & $\mathrm{P}<0.0005$ \\
\hline$\% \mathrm{CD} 3+\mathrm{CD} 4+$ & $55.3(50.2-61.2)$ & $44.4(38.5-51.2)$ & $\mathrm{P}<0.0005$ \\
\hline$\% \mathrm{CD} 3+\mathrm{CD} 8+$ & $21.6(17.6-26.2)$ & $20.3(15.7-24.9)$ & $\mathrm{P}=0.140$ \\
\hline$\% \mathrm{CD} 4 / \mathrm{CD} 8$ & $2.7(2.5-2.9)$ & $2.1(1.8-2.6)$ & $\mathrm{P}<0.0005$ \\
\hline$\% \mathrm{CD} 3+\mathrm{HLADR}+$ & $8.9(7.9-10.5)$ & $6.9(6.0-8.4)$ & $\mathrm{P}<0.0005$ \\
\hline
\end{tabular}

Legend: M- median, IQR- interquarterly rank

The mean values of the \% CD4 / CD8 lymphocyte ratio between mild burns, moderate severe burns, and severe burns on the day $7^{\text {th }}$ and on the day $14^{\text {th }}$ after burn trauma were significantly different, $\mathrm{p}<0.0005$, Table 5 .

\section{Analysis of CD3+HLA-DR + (\%) lymphocytes in burns of varying degrees}

On the day $7^{\text {th }}$ after burn trauma, $\%$ CD3 + HLA$\mathrm{DR}+$ lymphocytes were significantly different between mild, moderate, and severe burns, $p=0.021$. The average values of $\%$ CD3 HLA-DR + lymphocytes were significantly lower in severe burns compared to mild burns, $p=0.030$. There is no significant difference between moderateburns and severe burns, $p=0.762$, nor between mild burns compared to moderate burns, $p=$ 0.126 .

On the day $14^{\text {th }}$ after burn trauma, \% CD3 + HLA-DR + lymphocytes were significantly different between mild, moderate, and severe burns, $p=0.003$. $\%$ CD3 + HLA-DR + lymphocytes were significantly lower in severe burns compared to mild burns, $\mathrm{p}=$ 0.003 . There is no significant difference between moderate burns compared to severe burns, $p=0.232$. There is no significant difference between mildburns and moderate burns, $p=0.170$. The results of the analysis are shown in the table 6 .

The mean values of $\% \mathrm{CD} 3+\mathrm{Ly}, \% \mathrm{CD} 3+\mathrm{CD} 4+$ Ly, ratio o \%f CD4 / CD8 lymphocytes and \% CD3 +
HLA-DR + lymphocytes were significantly higher in partial thickness burn, compared to patients with full thickness burn on the dya $7^{\text {th }}$ after burn trauma, $\mathrm{p}<$ 0.0005. Average values of $\%$ CD3 + CD $8+$ lymphocytes did not differ significantly between patients with full-thickness burn compared to patients with partial-thickness burn, $p=0.140$; Table 7 .

On the day $7^{\text {th }}$ after burn trauma, $\%$ TBSA is negatively correlated with $\mathrm{CD} 3+\mathrm{CD} 4+(\%)$ lymphocytes, negatively correlated with \% CD3 lymphocytes,negatively correlated with the ratio of $\% \mathrm{CD} 4+/ \mathrm{CD} 8+$ lymphocytes, negatively correlated with $\% \mathrm{CD}+\mathrm{HLA}-\mathrm{DR}$ + lymphocytes. There is no correlation of \%TBSA with $\% \mathrm{CD} 3+\mathrm{CD} 8+$ lymphocytes.

By linear multivariate regression, on the day $7^{\text {th }}$ after burn trauma, we proved that \% CD3 lymphocytes have the greatest predictor importance for the assessment of immune damage, while the importance of other parameters is insignificant. The whole model, with all predictors, was statistically significant $(\mathrm{R}=0.919$, $\mathrm{R} 2=0845, \mathrm{~F}=108.9, \mathrm{p}<0.0005)$. The model classified $84 \%$ of the variability of the dependent variable, which can be explained by independent parameters.

By linear multivariate regression, on the day $14^{\text {th }}$ after burn trauma, we proved that \% CD4 + lymphocytes, \% CD3+lymphocytes and \%CD3HLA-DR+ lymphocytes have the greatest predictor importance for the assessment of immune damage $(\mathrm{R}=0.852, \mathrm{R} 2=$ $0.726, \mathrm{~F}=52.932, \mathrm{p}<0.0005)$, while the importance of 
Table 8. Predictor importance of lymphocytes for the assessment of immune damage

\begin{tabular}{|l|c|c|c|c|c|c|c|}
\hline \multirow{2}{*}{ Model } & \multicolumn{2}{|c|}{ Non-standard coeff. } & $\begin{array}{c}\text { Standard } \\
\text { coeficient }\end{array}$ & \multirow{2}{*}{ t } & \multicolumn{2}{c|}{ Sig. } & \multicolumn{2}{c|}{$95 \%$ CI for } \\
\cline { 2 - 6 } & B & Std. error & Beta & & & lower limit & upper limit \\
\hline 1 cont. & 45.757 & 6.87 & & 7.359 & $\mathrm{P}<0.0005$ & 33.445 & 58.032 \\
\hline CD4 & -0.256 & 0.068 & -0.289 & -3.774 & $\mathrm{P}<0.0005$ & -0.391 & -0.121 \\
\hline CD3 & -0.212 & 0.076 & -0.183 & -2.782 & 0.007 & -0.33 & -0.06 \\
\hline C3+HLADR & -0.841 & 0.408 & -0.138 & -2.059 & 0.043 & -1.653 & -0.028 \\
\hline
\end{tabular}

Dependent variable \% TBSA

other parameters is insignificant. The model classified $72 \%$ of the variability of the dependent variable, which can be explained by independent parameters Table 8 .

\section{DISCUSSION}

The consequences of thermal trauma are local and systemic. Responses to thermal injuries include cellular defense mechanisms, inflammation, immune disorders, and in extensive burns, a prolonged hypermetabolic response with weight loss, prolonged catabolic state, and organ dysfunction. Changes affecting the immune system include changes by the endocrine system, activation of the arachidonic acid cascade, and cytokine synthesis. The anti-inflammatory response includes increased levels of vasopressin, aldosterone, growth hormone, cortisol, glucagon, and catecholamines. Increased glucocorticoid levels inhibit the production of IFN-ã and IL-2, but not IL-4 and IL-10. Changes in cytokine levels damage the adaptive immune system during burns, especially the T lymphocyte population.

In our studies, we found pronouncedlymphopenia on the day $14^{\text {th }}$ compared to day $7^{\text {th }}$ in all groups of burns. The severity of the burn affected decrease in $T$ lymphocytes. The $\%$ of CD3 + CD $4+$ lymphocytes, on the day $7^{\text {th }}$ after the burn, is significantly lower in severe burns compared to mild burns and moderate burns and significantly lower in severe burns compared to moderate burns. On the day $14^{\text {th }}$ after the burn, there was a significant decrease in $\% \mathrm{CD} 3+\mathrm{CD} 4+\mathrm{Ly}$ compared to the day $7^{\text {th }}$ in moderate and severe burns, while in mild burns the decrease was not significant.Immunological T-cells respons are result of the synergistic action of CD4+ Ly with other T-Ly subclasses. The percentage of CD4+ T-lymphocytes is a key criterion for assessing the degree of damage, ie. immune system deficiencies. Immunodeficiency in burns is results a decrease in the $\%$ of $\mathrm{CD} 3+\mathrm{T}$ lymphocytes, and the decrease depends on the severity of the burn. Our study showed that on the day $7^{\text {th }}$ and the day $14^{\text {th }}$ after burn trauma, severe burns and moderate burns have significantly lowe $\%$ CD3 + Ly compared to mild burns. The differen- ce between moderate burns and severe burns, on the day $7^{\text {th }}$ and on the day $14^{\text {th }}$ after burn trauma, was not significant, although patients with severe burns had lower mean values $\% \mathrm{CD} 3+$ lymphocyte compared to patients with moderate burns.

The severity of the burn trauma no significantly reduces $\% \mathrm{CD}+\mathrm{CD} 8+$ lymphocyte on the day $7^{\text {th }}$ after the burn trauma, in our study. The $\%$ CD3 + CD $8+\mathrm{Ly}$, although lower in severe burns compared to the other two groups of burns, were not significantly reduced in severe burns compared to mild and moderate burns, as well as in moderate burns compared to mild burns. Although in our study, the severity of the burn did not significantly affect the decrease in \% CD3 + CD8 lymphocytes, indirectly, through reduced \% CD3+CD4+ lymphocytes, it may be an additional reason for immunosuppression. In our study, on the day $7^{\text {th }}$ after burn trauma, the mean values of $\% \mathrm{CD} 3+\mathrm{Ly}, \% \mathrm{CD} 4+\mathrm{Ly}$, activated lymphocytes (\% CD3 + HLA-DR + Ly) and the ratio of CD4 / CD8 lymphocyte were significantly lower in patients with full-thickness burns, compared to patients with partial-thickness burns. \% CD8 + Ly did not differ significantly between patients with full-thickness burns compared to partial-thickness burns. CD4+ lymphocytes have an immune memory and their presence is necessary to maintain the effector function of CD8+ cells in inflammation. Decreased \% CD3 + CD4 + lymphocytes impaired effectory function of \%CD3 + CD8 lymphocytes. In any case, changes in \% CD4 T lymphocytes are an important cause of immunosuppression in patients with burns.

On the day $14^{\text {th }}$ after burn trauma, the $\% \mathrm{CD} 3+$ CD8 + lymphocytes were higher than on the day $7^{\text {th }}$ in all groups of burns, but this increase was not significant compared to the day $7^{\text {th }}$. That the T cell immunosuppression is higher in higher \%TBSA, is shown by the ratio \% CD4 / CD8 lymphocyte. On the day $7^{\text {th }}$ andon the day $14^{\text {th }}$, the ratio $\%$ CD4/CD8 was significantly lower in severe burns compared to moderate burns and compared to mild burns. Mean values of ratio \%CD4 / CD8 lymphocytes on the day $14^{\text {th }}$ compared to the day $7^{\text {th }}$, after burn trauma, did not differ signi- 
ficantly in moderate and mild burns, but in the group of severe burns ratio of $\%$ CD 4 / CD8 was significantly lower on day $14^{\text {th }}$ compared to the day $7^{\text {th }}$.

The total number of lymphocytes is important for the immune defense of the organism, as well as the percentage of lymphocytes that carry HLA-DR antigen, $\%$ CD4 + lymphocytes and\% CD3 + lymphocytes. Immunosuppression, in our study, observed through the average values of CD3 + HLA-DR + (\%) lymphocytes in relation to the degree of severity of the burn, is most pronounced in severe burns. CD3 + HLA-DR +\%lymphocytes were significantly lower in severe burns compared to mild burns the day $7^{\text {th }}$ on the day $14^{\text {th }}$. Our research has shown that the mechanism of antigen recognition and the speed of reaction on the antigens depend on the severity of the burn. This mechanism is particularly weakened in severe burns, compared to the other two groups, in the first two weeks after the burn. Decreased HLA-DR expression is a sign of immunosuppression after a burn. The expression of HLA-DR antigen is associated with the role of lymphocytes as antigen-presenting cells. HLA-DR expression can be activated by anti-inflammatory cytokines, especially IL-10, TGF-â and PGE-2. Catecholamines released after burn trauma may increase HLA-DR expression on lymphocytes. CD3 + HLA-DR + cells are activated T-lymphocytes, with pronounced MHC class II membrane molecules, a class of major tissue tolerance complex. Activated T-lymphocytes, together with memory T-lymphocytes, are important for the rapid initiation of specific immune responses and that the involvement of inflammatory cells is important during the healing process of burned skin (4).

The suppression of the immune response is strongerby more severe the burn. On the day $7^{\text {th }}$ after the burn, $\%$ TBSA was negatively correlated with $\% \mathrm{CD} 3+$ CD4+ lymphocytes, was negatively correlated with $\% \mathrm{CD} 3+\mathrm{Ly}$, was negatively correlated with the ratio $\%$ CD4 / CD8 Ly andwas negatively correlated with\% CD3 + HLA-DR + Ly. \%TBSA were without significant correlation with $\%$ CD3 + CD8 + Ly. The inflammatory response, on the day $7^{\text {th }}$ in our study, and the T-cell immune response were negatively correlated.

Research by Wood JJ et al. (2), and Guanying YY et al. (5) suggest that $\mathrm{T}$ cell immunosuppression is associated with decreased production of IL-2, a cytokine that is primarily produced by peripheral blood mononuclear cells and Th1-Ly. Immunosuppression is also affected by increased production of IL-4 and IL-10, cytokines that reduce Th1-Ly function and redirect $\mathrm{T}$ lymphocyte differentiation in favor of Th2 lymphocyte subpopulation, andreducing Th1 lymphocyte phenotype. Boyce DE et al, found that IL-2 values return to normal values in a later stage, in burn healing phase
(6). The percentage of CD3 T-Ly and CD4 T-Ly in patients with burns is lower compared to healthy controls (7). HLA-DR expression is a sensitive indicator that reflects the activation and proliferation of lymphocytes after burn, and the rapid initiation of specific immunoreactions (4). CD8 lymphocytes recognize foreign antigens within MHC class I molecules. CD4 lymphocytes recognize antigens in complex with MHC class II molecules on the surface of antigen-presenting cells. During the burns, several changes in the T-lymphocyte population were observed. The poor response to mitogens is particularly pronounced (8). After burns, the values of anti-inflammatory cytokines increased: IL-4 and IL-10 (9). IL-4 and IL-10 may inhibit Th1-Ly activation for antigen presentation. Changes in the balance between $\mathrm{T}$ suppressor and $\mathrm{T}$ helper lymphocytes and the ratio of Th1-Ly to Th2-Ly are an important etiological factor in the suppression of the adaptive immune response.The reason for immunosuppression of patients with burns is also in CD8 lymphocytes, which are inhibited by PG-E2 released from monocytes (10). Nevertheless, a significant mediating role in immunosuppression is attributed to Th2 lymphocytes. Th2-Ly is produced by anti-inflammatory cytokines, including IL-6, which suppresses the production of CD4 + cells (11).

Immunosuppression in patients with burns is associated not only with a reduced number of T-lymphocytes, but also with a change in the capacity and ability of T-lymphocytes to activate after antigen stimulation, whatever its type (necrotic cells, products of thermally damaged cells, bacterial toxins, burnt tissue endotoxins) during thermal injury (8). Horfan AF. et al. examined the mitogenic response of lymphocytes of patients with burns after antigen stimulation and found that patients with severe burns have a reduced cellular immune response, not only due to decreased lymphocyte count, but also due to impaired function of circulating T-helper lymphocytes. T-lymphocyte damage is manifested by decreased mitogenesis in response to mitogens, reduced response to antigen stimulation and activation. The same authors believe that deregulation of the immune response, following burn trauma, occurs as a consequence of redistribution of T-lymphocytes in peripheral blood and tissues. Burn trauma is a trigger for the apoptotic T-Ly pathway, but the exact mechanism of the apoptosis pathway to date is unclear while preventing apoptosis of activated $\mathrm{T}$ lymphocytes through reduced Fas-ligand induction in the cell. It is thought that the products of activated macrophages, PGE-2, and transforming growth factor-â (TGF-â) may contribute to $\mathrm{T}$ lymphocyte suppression, primarily the Th-1 subpopulation of lymphocytes. In addition, PGE-2 inhibits CD8 + lymphocyte function (10). 
Mabrouk et al. (12), on the fourth day after burn trauma, found a decrease in the absolute number of CD3 lymphocytes, CD4 lymphocytes, CD8 lymphocytes, and a decrease in the ratio CD4 / CD8 lymphocyte, compared with healthy controls. They explain the decrease by the presence of immunosuppressive factors in burn patients. One of these factors, in their opinion, is the polymerized lipid-protein-complex of the cell membrane of the tissue damaged by the burn, the so-called burn toxin. The authors demonstrated that burn toxin inhibits the proliferation of normal lymphocytes after antigen stimulation. Not only does it inhibit the proliferation of normal lymphocytes after antigen stimulation, but the burn toxin has a toxic effect on lymphocyte proliferation and lowers the absolute number of lymphocytes in patients with burns, resulting in immunosuppression. Some authors observe certain parameters in isolation, such as e.g. the ratio CD4 / CD8 as indicators of immunosuppression. Rijola LF et al. (7) considered, in moderate burns, only the reduced CD4 / CD8 ratio gives prognostic significance in the further development of immunosuppression after burn trauma.

In the daily clinical practice of treating burns, it is very important to predict the extent to which immunosuppression is present in the burn patient. Our research showed that already on the day $7^{\text {th }}$ after the burn, CD3 lymphocytes have the greatest predictor significance of immunosuppression. On the day $14^{\text {th }}$, in addition to CD3 lymphocytes, CD4 lymphocytes and CD3 + HLA-DR + lymphocytes have a predictor of immunosuppression. It is possible that the decreased CD4 Ly number is due to the reduced CD3 Ly number (13). There are other reasons that lead to a decrease in the proliferation and maturation of $\mathrm{T}$ lymphocytes. Thus Schluter B, et al. (14) believe that IL-7, which grows during the first week after a burn, may reduce the proliferative and maturation capacities of T-Ly.

\section{CONCLUSION}

1. Changes in T lymphocytes are an important cause of immunosuppression in burn patients. T-lymphopenia is present in all burns regardless of the severity of the burn. T-lymphopenia is significantly lower on the day $14^{\text {th }}$ compared to the day $7^{\text {th }}$ after the burn.

2. T-lymphopenia, is stronger in higher $\%$ TBSA and deeper burns

3. Decreased values of subclass T lymphocytes should be interpreted as important markers of immune suppression assessment. An increase in \% CD3+HLA -DR + lymphocytes on the day $14^{\text {th }}$ compared to the day $7^{\text {th }}$ indicates the onset of a specific $\mathrm{T}$ immunoreac- tion. The severity of the burn affects the activation and proliferation of activated $\mathrm{T}$ lymphocytes.

4. On the day $7^{\text {th }}$ after burn trauma, \% TBSA is negatively correlated with CD3+CD4+(\%) lymphocytes, negatively correlated with \% CD3 lymphocytes, negatively correlated with the ratio of $\% \mathrm{CD} 4+/ \mathrm{CD} 8+$ lymphocytes, negatively correlated with \% CD+HLA -DR+ lymphocytes. There is no correlation of \% TBSA with \%CD3+CD8+ lymphocytes. \% CD3+ lymphocytes have the greatest predictor importance for the assessment of immune deficiency, on the day 7 th after burn trauma. \% CD4+Ly, \%CD3+ Ly and\%CD3+ HLA-DR+ lymphocytes have the greatest predictive importance for the assessment of immune deficiency, on the day $14^{\text {th }}$.

5. Immunosuppression observed through the average values of CD3+HLA-DR+(\%) lymphocytes in relation to the severity of the burn, is most pronounced in severe burns. CD3+ HLA-DR + (\%) lymphocytes were significantly lower in severe burn compared to mild burns on the day $7^{\text {th }}$ and on the day $14^{\text {th }}$.

6. Deeper burns, full-thickness burns, result in stronger suppression of the immune response. On the day $7^{\text {th }}$ after burn trauma, the mean values of $\% \mathrm{CD} 3$ Ly, \% CD4 + Ly, activated lymphocytes (\% CD3 + HLA-DR + Ly) and the ratio CD4 / CD8 lymphocyte were significantly lower in patients with full-thickness burns, compared to patients with partial-thickness burns burns. The depth of the burn has no significant reflection on $\% \mathrm{CD} 8+$ lymphocytes on the day $7^{\text {th }}$ after burn trauma.

\section{Abbreviations}

TBSA - Total Body Surface Area

ABA - American Burn Association

CD - cluster designation

Th Ly - T helper lymphocytes

CD8 T Ly - cytotoxic T lymphocytes

MHC II AC - major histocompatibility class II antigen complex

TNF - tumor necrosis factor

IL — interleukin

PG — prostaglandin

IFN — interferon

TGF - transforming growth factor

Conflict of Interests: The authors declare that there are no conflicts of interest related to this article.

Funding: None

\section{Licensing}

This work is licensed under a Creative Commons Attribution 4.0 International (CC BY 4.0) License. 


\title{
Sažetak
}

\section{ANALIZA LIMFOCITA PERIFERNE KRVI KOD OPEKOTINA RAZLIČITOG STEPENA TEŽINE U PROCENI IMUNOLOŠKE SUPRESIJE}

\author{
Arslanagic Selma, ${ }^{1}$ Karamehic Jasenko ${ }^{2}$ \\ ${ }^{1}$ Clinic for Reconstructive and plastic surgery, University Medical Center Sarajevo, \\ Sarajevo, Bosnia and Herzegovina \\ ${ }^{2}$ Institute of Immunology, University Medical Center Sarajevo, \\ Sarajevo, Bosnia and Herzegovina
}

Uvod: Opekotina, ovisno o stepenu težine ima za posledicu značajan patofiziološki odgovor.

Cilj istraživanja: Ciljevi istraživanja su ispitati reperkusije \% TBSA i reperkusije dubine opekotine na imunološki odgovor procenjujući: \%CD3+Ly, \%CD4 +Ly, \%CD8+Ly, \%CD3+HLA-DR+Ly iodnos \%CD4 + Ly/CD8+Ly.

Pacijenti i metode: Prema \%TBSA, pacijente smo podelili u 3 grupe: blage opekotine sa TBSA $\%<$ $15 \%$ (30 pacijenata), grupu srednje teških opekotina sa $\%$ TBSA od 15\%-25\% (30 pacijenata) i grupu sa $\%$ TBSA $>25 \%$ do $40 \%$ (30 pacijenata). Prema dubini opekotine, pacijente smo podelili u dve grupe: partial-thickness burns, (39 pacijenata), i full-thickness burns (51 pacijent). Pratili smo sledeće parametre: \% CD3+Ly, \% CD3+ CD4+Ly, \% CD3+CD8+Ly, \% CD3 +HLA-DR+Ly, i odnos CD4 / CD8 (\%) limfocita (7. i 14. dana nakon opekotine).

Rezultati: \%CD3+ Ly signifikantno je niži kod teških opekotina u poređenju sa srednje teškim opekotinama i u poređenju sa blagim opekotinama. \% CD3+CD4+ Ly signifikantno je niži kod teških opekotina u poređenju sa srednje teškim opekotinama kao i u poređenju sa blagim opekotinama 14. dana nakon opekotinske traume; takođe je niži kod umereno teških opekotina u odnosu na lake opekotine. Četrnaestog dana nakon opekotinske traume, odnos \% CD4 / CD8 nije signifikantno niži kod teških opekotina u odnosu na umereno teške opekotine; ali je signifikantno niži kod teških opekotina u poređenju sa blagim opekotinama, i

\section{REFERENCES}

1. Mason SA, Nathens AB, Byrne JP, Gonzales A, Fowler R, Karanicolas PJ, et al. Trends in the epidemiology of major burn injury among hospitalized patients: A population-based analysis. J Trauma Acute Care Surg. 2017; 83(5): 867-74.

2. Wood JJ, Rodrick ML, O’Mahony JB, Palder SB, Saporoschetz I, D,Eon P, et al. Inadequate interleukin 2 production. A fundamental immunological deficiency in patients with major burns. Ann. Surg. 1984; 200: 311-20.

3. Appendix B to hospital resources document. Guidelines for service standards and severity classifications in the treatment signifikantno je niži kod umereno teških opekotina u poređenju sa blagim opekotinama. \% CD3+HLA-DR + Ly signifikantno je niži kod teških i umereno teških opekotina u poređenju sa blagim opekotinama i 7. i 14. dana nakon opekotinske traume. Full-thickness burns ima signifikantno niže \%CD3+Ly, signifikantno niže $\% \mathrm{CD} 3+\mathrm{CD} 4+\mathrm{Ly}$, signifikantno niže \%CD3+HLA -DR+ Ly i signifikantno niži odnos \% CD4/CD8 limfocita $\mathrm{u}$ poređenju sa partial-thickness burns.

Zaključak: T limfociti periferne krvi jedan su od ključnih indikatora imunosupresije kod pacijenata sa opekotinskom traumom. Jačina imunosupresije zavisi od \% TBSA i dubine opekotine. Veći \%TBSA i fullthickness burns imaju signifikantno veću imunosupresiju, u poređenju sa manjim \%TBSA i partial-thickness burns. Sedmog dana nakon opekotinske traume, \% TBSA u negativnoj je korelaciji sa \%CD3+CD4+ limfocitima, u negativnoj korelaciji sa \% CD3 limfocitima, u negativnoj korelaciji sa odnosom \%CD4 + / CD8 + limfocita i u negativnoj korelaciji sa \% CD + HLA -DR + limfocitima. Nema korelacije \% TBSA sa \%CD3 +CD8+ limfocitima. \% CD3+ limfociti imaju najveći prediktorni značaj za procenu imunodeficijencije sedmog dana nakon opekotinske traume. \% CD4+Ly, $\%$ CD3 + Ly i \%CD3+HLA-DR + limfociti imaju najveći prediktorni značaj za procenu imunosupresije 14 . dana nakon opekotinske traume.

Ključne reči: opekotina, \%TBSA, full- thickness burns, partial-thickness burns, T limfociti, \% CD3+Ly, $\%$ CD3+ CD4+Ly, \% CD3+CD8+Ly, \% CD3+HLA -DR+Ly,omjer CD4 / CD8 (\%) limfocita.

of burn injury.American Burn Association. Bull. Am. Coll. Surg. 1984; 69(10): 24!8.

4. Sayed S, Bakry R, El-Shazly M, El-Oteify M, Terzak IS, Fekry M. Effect of major burns on early and late activating markers of peripheral blood T lymphocytes.Ann Burns Fire Disasters. 2012; 25(1): 17-21.

5. Yu G, Li Y, Ye L, Wang X, Zhang J, Dong Z, Jiang D. Exogenous peripheral blood mononuclear cells affect the healing process of deep-degree burns. Mol Med Rep. 2017; 16(6): 8110-22.

6. Boyce DE, Jones WD, Ruge F, Harding KG, Moore K. The role of lymphocytes in human dermal wound healing. Br J Dermatol. 2000; 143(1): 59-65. 
7. Rioja LF, Alonso P, de Haro J, de la Cruz J. Prognostic value of CD4/CD8 lymphocyte ratio in moderately burned patients. Burns. 1993; 19(3): 198-201.

8. Horgan AF, Mendez MV, O’RiordainDS, Holzheimer RG, Mannik JA, Rodrik ML. Altered gene transcription after burn injury results in depressed T-lymphocyte activation. Ann. Surg. 1994; 220(3): 342-51.

9. Yeh FL, LinWL, Shen HD. Changes in circulating levels of an anti-inflammatory cytokine interleukin 10 in burned patients. Burns. 2000; 26(5): 454-9.

10. Porter BO, Malek TR. Prostaglandin E2 inhibits T-cell-activation-induced apoptosis and Fas-mediated cellular cytotoxicity by blockade of Fas-ligand induction. Eur J Immunol. 2009; 29(7): 2360-5.

\section{Correspondence to/Autor za korespondenciju}

Selma Arslanagić

Clinic for Reconstructive and plastic surgery

of the University Medical Center in Sarajevo

71000, Sarajevo, Bolnička 25, Bosnia and Hezegovina

Tlf: +38733665831

Gsm: +38761359370

E-mail: selmaarsla@gmail.com
11. Hager S, Foldenauer AC, Rennekampff HO, Deisz R, Kopp R, Tenenhaus M, et al. Interleukin-6 serum levels correlate with severity of burn injury but not with gender. J Burn Care Res. 2018; 39(3): 379-86.

12. Mabrouk A, Mabrouk RR, Sabry M, Fedway SF. Interleukin-6, CD4, and CD8 Subsets of T-Lymphocytes in population of Egyptian Burn Patient. Ann Burns Fire Disasters. 1997; 10(2): 85-9.

13. Kunes P, Krejsek J. CD4+ lymfopenie a pooperacní imunosuprese v kardiochirurgii ŠCD4 lymphopenia and postoperative immunosuppression in cardiac surgeryĆ. Cas Lek Cesk. 2000; 139(12): 361-8.

14. Hur J, Yang HT, Chun W, Kim JH, Shin SH, Kang HJ, et al. Inflammatory cytokines and their prognostic ability in cases of major burn injury. Ann Lab Med. 2015; 35(1): 105-10. 